\section{Cells come of age}

\section{Dennis Bray}

Annual Review of Cell Biology, Vol. 1 1985. Edited by George E. Palade, Bruce M. Alberts and James A. Spudich. Annual Reviews Inc., 4139 El Camino Way, Palo Alto, California 94306, USA:1985. Pp.580. $\$ 27$ (North America), \$30 (elsewhere).

REVIEWING reviews can be a vertiginous business, especially in a field such as cell biology in which any single experimental observation may be caught up and reflected from a ramifying literature, like images in a Hall of Mirrors. On the red blood cell cytoskeleton, for example, you will have a choice of a dozen or more reviews written in the past four years. All have the same viewpoint (no spicy controversies here) and offer more or less the same litany of facts. It is reasonable to ask how useful they are: do we need more reviews?

Well, yes, we do, at least when they are as authoritative and critical as those published by Annual Reviews Inc. Founded in 1929 , the company is a non-profit-making organization and produces volumes of reviews of scientific subjects at a remarkably low price. The directors, editors and authors all contribute their energies and talents for free, and in the interests of their science they are very conservative in starting new series. Beginning with the Annual Review of Biochemistry in 1931, the company now produces 27 volumes annually: a remarkably small number when one considers the range of subjects covered and the awesome increase in published literature in 55 years. New volumes are introduced only reluctantly, so that when one does appear it is a mark of recognition - a coming of age.

Some material in the new Annual Review of Cell Biology inevitably overlaps other disciplines. The articles on intermediate filaments, fibronectin, acetylcholine receptors and actin-binding proteins could as well have stayed in the parental Annual Review of Biochemistry. But the main part of the volume is distinctive in content and deals with a higher level of organization. Accounts of structures such as the brush border, the membrane cytoskeleton and microtubule organizing centres, and of organelles such as peroxisomes and Golgi apparatus, are complemented by refreshing, integrative reviews of the processes of protein targeting, endocytosis and membrane traffic, and the establishment of cell polarity in eukaryotes and prokaryotes.

The emphasis is still strongly molecular, and only one article - an excellent account of cell migration in the embryo by Thiery, Duband and Tucker — treats cells as the sentient creatures we all know them to be. Obviously molecules are easier to study and generate more data. But cell biology and molecular biology are not the same (despite some confused statements to this effect in the preface), and it is a pity that such an influential volume does not have more on the lineage, differentiation, behaviour and tissue interactions of the eponymous cell.

Within the rigidly defined format of the Annual Review volume, many excellent features are to be found in the book. There are more illustrations than usual, adding greatly to the interest and comprehensibility of a subject that deals in organization and structure (line diagrams are probably more effective than halftones in such an economically produced volume). It is also pleasant to discover how readable

\section{Scientific anatomy}

\section{Philip Gummett}

About Science. By Barry Barnes. Basil Blackwell:1985. Pp.163. Hbk £19.50, $\$ 24.95 ; p b k £ 6.50, \$ 8.95$.

SCIENCE is the dominant form of cognitive knowledge in all modern societies. What counts as empirical knowledge in these societies is very close to being what scientists and associated experts allow so to count. How this state of affairs came about, and what it entails for both science and society, are the main themes of this book.

These themes are the bread and butter of the social studies of science, a field which developed largely from the 1960s, when there was a flurry of interest in the possibility of a "science of science". Although that goal has long been abandoned, we do now have a richer understanding of science as a social institution. Unfortunately, much of the relevant literature is written only for the cognoscenti. Barnes redresses the balance well with this extremely lucid book. His intended audience is undergraduates and sixthformers who are studying natural science and wish to learn more about science as an activity. But the book is so well written that it should attract a much wider readership.

Barnes describes how science became central to society during the Industrial Revolution. This was not because there were large numbers of scientists, nor because of any misplaced belief in its usefulness. Rather, science was for the rising commercial and industrial classes what the Bible and the classics had been for the old landed gentry and aristocracy. As science developed so did specialization, and with it came social processes for authenticating scientific knowledge and granting admis- many of the articles are. Back in 1950, the first volume of the Annual Review of Physical Chemistry regaled its readers with sentences several pages long, containing lists of references and chemical names and one verb. We have come a long way since then. Many of the reviews in this new volume could be enjoyed by informed readers outside the immediate area of specialization, especially where authors have ventured to bring the facts together in a hypothesis. The marvellously complete account of mitosis and meiosis by Murray and Szostak creates calm in a tormented universe; right or wrong, intelligent models of this kind certainly make facts easier to remember.

Dennis Bray is in the Medical Research Council's Cell Biophysics Unit, 26-29 Drury Lane, London WC2B $5 R L, U K$

sion to the body of acknowledged scientists. Within this new social institution, recognition by one's peers served the purpose that money served in the wider society: scientists sought recognition of their work, not as an end in itself, but because with it they could more readily advance their careers in the ways that they wanted.

The unequal distribution of recognition among the scientific community means that the word of some scientists counts more than that of others. This has the useful consequence that the authority of the most highly-regarded scientists acts as a filter for the mass of data which scientists encounter daily, and so allows them to survive without having constantly to go back to basics. This portrait of scientific activity contradicts, of course, the popular picture of scientists as always questioning everything.

The authority structures that arise within science extend into the wider society. This did not happen by accident. As part of their campaign in the nineteenth century for social acceptance, scientists fought the church for recognition as the authoritative voice on issues to do with natural phenomena. Their victory is now more or less complete, and this raises the question today of the possible political domination of society by experts. Barnes is sceptical of this argument. For him, society is dominated through science and technology rather than by them. He also disputes the proposition that, if only all citizens were properly informed about the issues of the day, rationally correct decisions would be made by simple aggregation of individual preferences. Such aggregation is neither simple nor even necessarily rational. The science of society remains as remote as the science of science.

Philip Gummett is in the Department of Science and Technology Policy, University of Manchester, Manchester M13 9PL, UK. 